Journal of Healthcare Technology and Medicine Vol. 3 No. 2 Oktober 2017

Universitas Ubudiyah Indonesia

e-ISSN : 2615-109X

\title{
FAKTOR-FAKTOR YANG BERHUBUNGAN DENGAN STATUS GIZI ANAK BATITA (1-2 TAHUN) SELAMA DISUSUI DI WILAYAH KERJA PUSKESMAS INGIN JAYA KABUPATEN ACEH BESAR TAHUN 2017
}

\author{
Factors Related To Status Of Children's Nutrition (1-2 Years) For During The Working \\ Area Of Puskesmas Want To Jaya, Aceh District, Big, 2017 \\ Ruri Widyasari*1 ${ }^{*}$, Cici Puspita Sari \\ Koresponding email : ruri@uui.ac.id*1 \\ Universitas Ubudiyah Indonesia
}

\begin{abstract}
Abstrak
Masalah kekurangan konsumsi pangan bukanlah merupakan hal yang baru, namun masalah ini tetap aktual terutama di negara-negara sedang berkembang sebab mempunyai dampak yang sangat nyata terhadap timbulnya masalah gizi. Di Puskesmas Ingin Jaya Kabupaten Aceh Besar Tahun 2017 diperoleh permasalahan tentang status gizi anak batita umur 1-2 tahun antara lain Pengetahuan ibu, pendapatan dan jumlah anggota keluarga terhadap status gizi anak batita (1-2) tahun. Penelitian ini bertujuan untuk mengetahui Faktor-faktor Yang Berhubungan Dengan Status Gizi Anak Batita (1-2 tahun) Selama Disusui di Wilayah Kerja Puskesmas Ingin Jaya Kabupaten Aceh Besar Tahun 2011. Penelitian ini bersifat analitik dengan desain Cross Sectional yang dilakukan pada tanggal 19 sampai 21 November 2017 untuk mengetahui faktor-faktor yang berhubungan dengan status gizi anak batita (1-2 tahun) selama disusui di Wilayah Kerja Puskesmas Ingin Jaya Kabupaten Aceh Besar Tahun 2017, yaitu Pengetahuan, Pendapatan dan Jumlah anggota keluarga dengan jumlah populasi 355 ibu dan sampel 78 ibu. Analisa data menggunakan metode univariat yaitu dengan distribusi frekuensi dan bivariat yaitu dengan menggunakan uji Chi Square (x2). Berdasarkan hasil penelitian diperoleh bahwa ada hubungan antara variabel pengetahuan dengan status gizi anak batita (1-2 tahun) dengan P. Value < 0,05 yaitu 0,001 , begitu juga dengan variabel pendapatan diperoleh adanya hubungan dengan $P$. Value $<0,05$ yaitu 0,003 . Tetapi berbeda dengan variabel jumlah anggota keluarga, tidak ada hubungan antara variabel jumlah anggota keluarga terhadap status gizi anak batita (1-2 tahun) dengan P. Value $>0,05$ yaitu 0,454. Diharapkan kepada setiap ibu agar memberikan zat gizi atau makanan seimbang dan ASI Ekslusif kepada anak mereka sehingga anak mereka memiliki status gizi yang baik sehingga pertumbuhan otak mereka menjadi sempurna dan dapat meningkatkan derajat kesehatan masyarakat.
\end{abstract}

\section{Kata Kunci : Pengetahuan, Pendapatan, Jumlah Anggota Keluarga dan Status Gizi Anak Batita (1-2 Tahun)}

\begin{abstract}
The problem of lack of food consumption is not new, but this problem remains actual, especially in developing countries because it has a very real impact on the emergence of nutritional problems. In the Health Center of Want Jaya in Aceh Besar Regency in 2017, problems were obtained regarding the nutritional status of toddlers aged 1-2 years including the knowledge of mothers, income and the number of family members of the nutritional status of toddlers (1-2) years. This study aims to determine the Factors Associated with the Nutritional Status of Toddler Children (12 years) During Breastfeeding in the Greater Jakarta Health Center Work Area in Aceh Besar District 2011. This research is analytic with Cross Sectional design conducted on 19 to 21
\end{abstract}


Journal of Healthcare Technology and Medicine Vol. 3 No. 2 Oktober 2017

Universitas Ubudiyah Indonesia

e-ISSN : 2615-109X

November 2017 to find out factors related to the nutritional status of toddlers (1-2 years) during breastfeeding in the Greater Jakarta Health Center working area in 2017, namely Knowledge, Income and Number of family members with a population of 355 mothers and a sample of 78 mother. Data analysis using univariate methods, namely the frequency distribution and bivariate, namely by using the Chi Square test (x2). Based on the results of the study it was found that there is a relationship between knowledge variables with the nutritional status of toddlers (1-2 years) with $P$. Value $<0.05$ is 0.001 , as well as the income variable obtained by a relationship with $P$. Value $<0.05$ which is 0.003 . But unlike the variable number of family members, there is no relationship between the variable number of family members on the nutritional status of toddlers (1-2 years) with $P$. Value $>0.05$ which is 0.454 . It is expected for every mother to provide balanced nutrition or food and exclusive breastfeeding to their children so that their children have a good nutritional status so that their brain growth becomes perfect and can improve the degree of public health.

Keywords: Knowledge, Income, Number of Family Members and Nutritional Status of Toddlers (1-2 Years)

\section{PENDAHULUAN}

Masalah kekurangan konsumsi pangan bukanlah merupakan hal yang baru, namun masalah ini tetap aktual terutama di negara-negara sedang berkembang sebab mempunyai dampak yang sangat nyata terhadap timbulnya masalah gizi. Salah satu faktor yang menyebabkan keadaan ini terjadi adalah bertambahnya jumlah penduduk di berbagai Negara sedang berkembang yang cenderung meningkat terus, sedangkan pertambahan produksi pangan belum mampu mengimbanginya walaupun telah diterapkan beragam teknologi mutakhir.

Dari laporan yang ada laju pertumbuhan penduduk di Asia Tenggara tetap merupakan yang tertinggi di dunia. Selama jangka waktu sepuluh tahun angka rata-rata pertumbuhan penduduk dari empat negara Asia Tenggara (Indonesia, Malaysia, Filiphina dan Muangthai) tercatat 29,8\% dimana memang angka ini ternyata lebih tinggi dari rata-rata semua negara sedang berkembang yang menunjukkan sebesar 24,9\% (Suhardjo, 2003).

Pemberian ASI secara baik, benar dan makanan pendamping yang diolah sendiri merupakan upaya pencegahan yang utama dalam mengatasi masalah kekurangan gizi pada anak. Rendahnya pemberian ASI merupakan ancaman bagi tumbuh kembang anak yang akan berpengaruh pada pertumbuhan dan perkembangan kualitas SDM secara umum. Seperti yang diketahui bayi yang tidak diberi ASI dan makanan pendamping setelah usia 6 bulan yang teratur, baik dan tepat, dapat mengalami kekurangan gizi (Depkes, 2011).

Pada tahun 2003 Universal Children Foundation (UNICEF) menyatakan bahwa pemberian Air Susu Ibu (ASI) Eksklusif sampai usia enam bulan dapat mencegah kematian 1,3 juta anak 
Journal of Healthcare Technology and Medicine Vol. 3 No. 2 Oktober 2017

Universitas Ubudiyah Indonesia

e-ISSN : 2615-109X

berusia dibawah lima tahun, suatu penelitian di Ghana yang diterbitkan jurnal pediatries menunjukkan 16 kematian bayi dapat dicegah melalui pemberian ASI pada bayi sejak hari pertama kelahirannya, angka ini naik menjadi 22\% jika pemberian ASI dimulai dalam satu jam pertama setelah kelahiran bayi (Kompas, 2007).

Pemberian ASI merupakan metode pemberian makan anak yang terbaik terutama pada anak umur 1-2 tahun. Guna memenuhi semua kebutuhan bayi perlu ditambah dengan Makanan Pendamping ASI (MP-ASI). MP-ASI adalah makanan atau minuman yang mengandung gizi diberikan kepada bayi/anak untuk memenuhi kebutuhan gizinya. MP-ASI diberikan mulai usia 4 bulan sampai 24 bulan. Semakin meningkat usia bayi/anak, kebutuhan akan zat gizi semakin bertambah karena tumbuh kembang sedangkan ASI yang dihasilkan kurang memenuhi kebutuhan gizi. MP-ASI merupakan makanan peralihan dari ASI ke makanan keluarga. Pengenalan dan pemberian MP-ASI harus dilakukan secara bertahap baik bentuk maupun jumlahnya sesuai dengan kemampuan pencernaan bayi/anak. Pemberian MP-ASI yang cukup dalam hal kualitas dan kuantitas penting untuk pertumbuhan fisik dan perkembangan kecerdasan anak yang bertambah pesat pada periode ini (Refkes,2008).

Berdasarkan latar belakang diatas, dapat di simpulkan bahwa ada berbagai faktor yang mempengaruhi status gizi anak batita (1-2 tahun) selama di susui. Untuk itu peneliti tertarik ingin mengetahui Faktor-faktor Yang Berhubungan Dengan Status Gizi Anak Batita (1-2 tahun) Selama Disusui di Wilayah Kerja Puskesmas Ingin Jaya Kabupaten Aceh Besar Tahun 2017.

\section{METODE PENELITIAN}

Penelitian ini bersifat analitik dengan desain Cross Sectional, dimana variable bebas dan terikat diteliti pada saat yang bersamaan saat penelitian dilakukan, yang bertujuan untuk mengetahui faktor-faktor yang berhubungan dengan status gizi anak batita (1-2 tahun) selama disusui di Wilayah Kerja Puskesmas Ingin Jaya Kabupaten Aceh Besar Tahun 2017.

Populasi dalam penelitian ini adalah seluruh ibu yang mempunyai anak batita (1-2 tahun) yang pernah berobat dan berkunjung ke Puskesmas Ingin Jaya Kabupaten Aceh Besar yang berjumlah 355 ibu. Sampel penelitian ini akan diambil dari seluruh desa yang ada di wilayah kerja Puskesmas Ingin Jaya Kabupaten Aceh Besar.

Adapun Kriteria sampelnya adalah sebagai berikut :

1. Ibu yang mempunyai anak balita umur 1-2 tahun. 
Journal of Healthcare Technology and Medicine Vol. 3 No. 2 Oktober 2017

Universitas Ubudiyah Indonesia

e-ISSN : 2615-109X

2. Ibu bersedia menjadi responden.

3. Ibu dapat membaca dan menulis.

4. Ibu sehat mental dan tidak tuna wicara.

\section{HASIL DAN PEMBAHASAN}

\section{Tabel 1}

Karakteristik Anak Berdasarkan Umur dan Berat Badan di Wilayah Kerja Puskesmas Ingin Jaya Kabupaten Aceh Besar Tahun 2017

\begin{tabular}{|c|c|c|c|}
\hline No. & Karakteristik & Frekuensi (jml) & Persentase (\%) \\
\hline 1. & Umur Anak : & 3 & 4 \\
& $-6-12$ bulan & 38 & 49 \\
& $-13-18$ bulan & 37 & 47 \\
& $-\quad 19-24$ bulan & - & - \\
\hline 2. & $-\quad>24$ bulan & 38 & 49 \\
& Berat Badan Anak : & 40 & 51 \\
& $-\quad 5-10 \mathrm{~kg}$ & - & - \\
\hline
\end{tabular}

Berdasarkan Tabel 1 diketahui bahwa Anak Batita (1-2 Tahun) yang memiliki umur 6 - 12

bulan adalah sebanyak $4 \%$, umur 13 - 18 bulan sebanyak 49\% dan umur $19-24$ bulan sebanyak $47 \%$. Sedangkan menurut karakteristik berat badan diketahui bahwa anak yang memiliki berat badan 5 - $10 \mathrm{~kg}$ adalah sebanyak $49 \%$ dan yang memiliki berat badan 10 - $15 \mathrm{~kg}$ adalah sebanyak $51 \%$.

Berdasarkan tabel 2 di bawah ini diketahui bahwa ibu yang memiliki umur 20 - 30 tahun adalah sebanyak $56 \%$, ibu yang memiliki umur 31 - 40 tahun sebanyak $41 \%$ dan ibu yang memiliki umur di atas 40 tahun sebanyak $3 \%$. Menurut karakteristik pendidikan ibu di wilayah kerja puskesmas Ingin Jaya paling dominan adalah SD - SMP (50 \%), SMA (42 \%) sedangkan perguruan tinggi hanya $8 \%$. Sedangkan menurut pekerjaan yang paling dominan adalah Ibu Rumah Tangga sebanyak $69 \%$.

Tabel 2

Karakteristik Ibu Berdasarkan Umur, Pendidikan dan Pekerjaan di Wilayah Kerja Puskesmas Ingin Jaya Kabupaten Aceh Besar Tahun 2017

\begin{tabular}{|c|c|c|c|}
\hline No. & Karakteristik & $\begin{array}{c}\text { Frekuensi } \\
(\text { Jml })\end{array}$ & Persentase (\%) \\
\hline 1. & Umur Ibu : & 44 & 56 \\
& $-20-30$ tahun & 32 & 41 \\
& $-31-40$ tahun & 2 & 3 \\
\hline 2. & $->40$ tahun & 39 & 50 \\
& Pendidikan Ibu : & 33 & 42
\end{tabular}


Journal of Healthcare Technology and Medicine Vol. 3 No. 2 Oktober 2017

Universitas Ubudiyah Indonesia

e-ISSN : 2615-109X

\begin{tabular}{|c|c|c|c|} 
& $-\quad$ Perguruan Tinggi & 6 & 8 \\
\hline 3. & Pekerjaan Ibu : & 54 & 69 \\
& $-\quad$ Ibu Rumah Tangga & 6 & 8 \\
& - Petani & 11 & 14 \\
& - Pedagang & 7 & 9 \\
\hline
\end{tabular}

Berdasarkan uji Chi Square menunjukkan bahwa ada hubungan antara pengetahuan dengan status gizi anak batita (1 - 2 tahun) di wilayah kerja Puskesmas Ingin Jaya Kabupaten Aceh Besar Tahun 2017 ( P. value = 0,001 < 0,05 ). Tingginya kasus malnutrisi di Indonesia menunjukkan masih rendahnya tingkat kesadaran masyarakat mengenai pengetahuan gizi.

Pengetahuan gizi bagi masyarakat luas dan kasus gizi buruk di Indonesia perlu mendapat perhatian bersama. Kurang gizi disebabkan oleh tiga faktor yaitu kemiskinan, ketidak tahuan, dan penyakit. Ketidak tahuan menyebabkan tidak diberikannya makanan yang cukup kualitas maupun kuantitas. pengetahuan gizi yang dimiliki ibu akan mempengaruhi pemberian makan kepada anaknya (Kania, 2010).

Semakin bertambah pengetahuan gizi ibu, maka seorang ibu akan semakin mengerti jenis dan jumlah makanan untuk dikonsumsi seluruh anggota keluarganya termasuk anak balitanya. Hal ini dapat meningkatkan kesejahteraan anggota keluarga sehingga dapat mengurangi atau mencegah gangguan gizi pada keluarga (EY, 2011).

Menurut hasil penelitian Komsatiningrum (2008) status gizi batita dipengaruhi oleh tingkat pengetahuan gizi ibu. Bila ibu memiliki tingkat pengetahun gizi yang tinggi maka status gizi anak dan pola konsumsi anak akan baik pula. Berdasarkan penelitian Komsatiningrum tentang status gizi di desa Meger Kabupaten Klaten diperoleh bahwa 33 responden (44,6 \%) memiliki tingkat pengetahuan yang baik, 35 responden $(47,3 \%)$ memiliki tingkat pengetahuan cukup dan 6 responden $(8,1 \%)$ memiliki tingkat pengetahuan yang rendah.

Menurut penelitian lain yang dilakukan oleh Zuraida (2007) tentang status gizi anak di Puskesmas Purwosari Surakarta diperoleh bahwa ada hubungan antara pengetahuan ibu tentang gizi dengan meningkatnya berat badan balita di Puskesmas tersebut.

Menurut asumsi peneliti diperoleh adanya hubungan antara pengetahuan dengan status gizi anak batita ( 1 - 2 tahun ). Karena semakin baik pengetahuan ibu tentang gizi maka semakin baik pula status gizi anak batita ( $1-2$ tahun ). Pengetahuan memiliki peran yang sangat penting dalam meningkatkan status gizi anak batita, karena ibu yang memiliki tingkat pengetahuan yang tinggi akan memberikan pola makan/konsumsi yang baik dan bergizi bagi anaknya. Berbeda dengan ibu 
Journal of Healthcare Technology and Medicine Vol. 3 No. 2 Oktober 2017

Universitas Ubudiyah Indonesia

e-ISSN : 2615-109X

yang memiliki tingkat pengetahuan rendah mereka cenderung memberikan makanan yang tidak seimbang kepada anaknya.

Berdasarkan uji Chi Square menunjukkan bahwa ada hubungan antara pendapatan dengan status gizi anak batita (1 - 2 tahun) di wilayah kerja Puskesmas Ingin Jaya Kabupaten Aceh Besar Tahun 2011 ( $\mathrm{P}$. value $=0,003<0,05$ ). Anak balita merupakan kelompok yang menunjukkan pertumbuhan badan yang pesat, sehingga memerlukan zat gizi yang tinggi setiap kg Berat Badannya.

Pendapatan suatu keluarga merupakan salah satu unsur yang dapat mempengaruhi status gizi. Hal ini menyangkut daya beli keluarga untuk memenuhi kebutuhan konsumsi makan. Masa balita sangat tergantung pada Ibu atau pengasuhnya sehingga pertumbuhan dan perkembangannya sangat tergantung pada pola asuh gizinya (Ninik, 2005).

Pendapatan keluarga mempunyai peran yang penting terutama dalam memberikan efek terhadap taraf hidup mereka. Efek di sini lebih berorientasi pada kesejahteraan dan kesehatan, dimana perbaikan pendapatan akan meningkatkan tingkat gizi masyarakat. Pendapatan akan menentukan daya beli terhadap pangan dan fasilitas lain (pendidikan, perumahan, kesehatan, dll) yang dapat mempengaruhi keadaan status gizi terutama balita (EY,2011).

Menurut penelitian Ninik (2015) tentang pendapatan keluarga terhadap pola asuh gizi di Demak diperoleh bahwa ada hubungan antara pendapatan keluarga dengan pola asuh gizi anak batita. Keluarga yang memiliki tingkat pendapatan yang tinggi cenderung akan meningkatkan status gizi anak balitanya. Berbeda dengan hasil penelitian yang dilakukan oleh Rahyaningsih, tingkat pendapatan dan pengeluaran pangan keluarga tidak mempunyai hubungan dengan konsumsi zat gizi anak balita.

Menurut asumsi peneliti diperoleh adanya hubungan antara pendapatan dengan status gizi anak batita ( 1 - 2 tahun ). Dari 53 orang responden diperoleh tingkat pendapatan rendah yang memiliki status gizi baik sebanyak 20 orang ( $37,7 \%$ ) dan status gizi buruk sebanyak 33 orang $(62,3 \%)$. Pendapatan yang rendah akan mempengaruhi pola konsumsi makan keluarga terutama anak. Jika keluarga memiliki tingkat pendapatan yang tinggi maka segala kebutuhan akan mudah dipenuhi begitu pula dengan kebutuhan konsumsi dan gizi anak. 
Journal of Healthcare Technology and Medicine Vol. 3 No. 2 Oktober 2017

Universitas Ubudiyah Indonesia

e-ISSN : 2615-109X

KESIMPULAN

1. Ada hubungan antara variabel pengetahuan dengan status gizi anak batita umur (1-2 tahun ) di wilayah kerja Puskesmas Ingin Jaya Kabupaten Aceh Besar Tahun 2011, dengan $\mathrm{P}$. value $=0,001<0,05$.

2. Ada hubungan antara variabel pendapatan dengan status gizi anak batita umur (1-2 tahun ) di wilayah kerja Puskesmas Ingin Jaya Kabupaten Aceh Besar Tahun 2011, dengan P. value $=0,003<0,05$.

3. Tidak Ada hubungan antara variabel jumlah anggota keluarga dengan status gizi anak batita umur (1-2 tahun ) di wilayah kerja Puskesmas Ingin Jaya Kabupaten Aceh Besar Tahun 2011, dengan P. value $=0,454>0,05$.

\section{DAFTAR PUSTAKA}

Ahira, Anne, 2011. Fungsi Dan Manfaat Gizi Bagi Tubuh, (internet) tersedia dalam \{http://www.AnneAhira.com\}, diakses tanggal 9 Agustus 2017.

Bidansmart, 2010. Ilmu Gizi Secara Umum, (internet) tersedia dalam \{http://www.Bidansmart.com\}, diakses tanggal 9 Agustus 2017.

Departemen Kesehatan RI, 2007. Pedoman Pemberian Makanan Bayi dan Anak Dalam

Situasi Darurat, Jakarta : Bina Gizi Masyarakat.

Dinas Kesehatan Aceh, 2010. Masalah Gizi Di Aceh, (internet) tersedia dalam \{http://www.dinkes.acehprov.go.id\}, diakses tanggal 20 September 2011.

Dien, 2011. Kasus Gizi Buruk Di Aceh Masih Tinggi, (internet) tersedia dalam \{http://www.Aceh-Kita-Berita-Lifestyle.html\}, diakses tanggal 9 Agustus 2011.

Eman, 2011. Kasus Gizi Buruk Menurun, (internet) tersedia dalam \{http://www.gizi.net.html\}, diakses tanggal 9 Agustus 2011.

Dan Pengetahuan Gizi Ibu Hamil Di Kabupaten Kendal, (internet) tersedia dalam \{http://www.diponegoro-university\},

Rokhana, Ninik Asri, 2015. Hubungan Pendapatan Keluarga Dengan Pola Asuh Gizi Anak

Balita di Betokan Demak, (internet) tersedia dalam \{http://www.Digilib-Unnes

Siswono, 2010. Kasus Gizi Buruk, (internet) tersedia dalam \{http://www.gizi.net.html\}, Utami, 2001. Bayi Sehat Berkat ASI Eksklusif, Jakarta : PT Alex Gramedia Compitundo.

Zulfia, Muksana, 2007. Faktor-faktor yang Mempengaruhi Kelancaran Air Susu Ibu, Politeknik Kesehatan NAD. 